\title{
PERANCANGAN SISTEM INFORMASI PENGOLAHAN DATA LAPORAN HASIL PRODUKSI PADA PT.CENTRAL SARANA PANCING
}

\author{
Achmad Rachmat ${ }^{1}$, Rasyid Tarmizi ${ }^{2}$, Firdaus Abdulrakhman Saputra ${ }^{* 3}$ \\ ${ }^{1}$ Program Studi Komputerisasi Akuntansi Fakultas Sains dan Teknologi Universitas Raharja \\ ${ }^{2}$ Program Studi Manajemen Retail Fakultas Ekonomi dan Bisnis Universitas Raharja \\ ${ }^{3}$ Program Studi Sistem Informasi Fakultas Sains dan Teknologi Universitas Raharja \\ E-mail: ${ }^{1}$ achmad.rachmat@ raharja.info,${ }^{2}$ rasyid@ raharja.info, ${ }^{* 3}$ firdaus.saputra@ raharja.info
}

\begin{abstract}
Abstrak
PT. Central Sarana Pancing seringkali menghadapi permasalahan pada pengolahan data laporan hasil produksi. Dalam pengolahan data laporan hasil produksi yang dilakukan,masih ada beberapa kekurangan yaitu proses pencatatan laporan hasil produksi yang dilakukan masih menggunakan kertas dan tidak bisa melakukan penginputan laporan hasil produksi di hari yang sama karena laporan hasil produksi dicatat di form hasil produksi menggunakan kertas sehingga membutuhkan waktu yang sangat lama dalam mengolah data dan penyimpanan data-datanya masih kurang aman dan kurang tertata dengan baik karena tidak adanya tempat penyimpanan data yang baik seperti kertas laporan hasil produksi bertumpuk diatas meja sehingga laporan hasil produksi bisa hilang ataupun bisa tercampur dengan laporan hasil produksi yang sudah di input. Berdasarkan masalah-masalah tersebut maka penulis mengusulkan pembuatan aplikasi pengolahan data laporan hasil produksi yang mudah dioperasikan dengan cepat, membuat sistem yang mudah di akses oleh bagian produksi dan mempunyai tempat penyimpanan data yang aman sehingga data-data yang ada tidak mudah hilang dan juga penyimpanan data menjadi lebih terintegrasi.
\end{abstract}

Kata Kunci-laporan hasil produksi, pengolahan data, penyimpanan data.

\begin{abstract}
PT. Central SaranaPancingoften faces problems in processing production report data. In processing the production report data, there are still some shortcomings, namely the process of recording the results of production reports that are still using paper and can not input production reports on the same day because the production report is recorded on the production form using paper so that it takes time the very long time in processing data and storing the data is still not safe and less well-organized because there is no good data storage place such as paper production reports stacked on the table so that the production reports can be lost or can be mixed with the production reports that have been inputed. Based on these problems, the authors propose making a production report data processing application that is easy to operate quickly, making a system that is easily accessible by the production department and has a secure data storage so that existing data is not easily lost and also data storage become more integrated.
\end{abstract}

Keywords - reports on production, data processing, data storage. 


\section{PENDAHULUAN}

PT. Central Sarana Pancing merupakan perusahaan yang bergerak di bidang manufaktur. PT.Central Sarana Pancing mempunyai jenis barang yang berbeda-beda. Di lain pihak, pengembangan sumber daya manusia akan tetap menjadi perhatian bagi pihak PT. Central Sarana Pancing, karena PT. Central Sarana Pancing percaya bahwa mutu sumber daya manusia yang tinggi akan menghasilkan kreatifitas dan inovasi dalam menghasilkan jenis barang, menyediakan produk yang berkualitas dan selalu mengutamakan kepuasan pelanggan dengan memberikan pelayanan yang baik.

Pada PT. Central Sarana Pancing yang dilakukan oleh bagian produksi masih memiliki beberapa kekurangan diantaranya proses pencatatan laporan hasil produksi yang dilakukan oleh bagian produksi masih menggunakan kertas dan tidak bisa melakukan penginputan laporan hasil produksi di hari yang sama karena laporan hasil produksi dicatat diform hasil produksi menggunakan kertas.Hal ini dirasa kurang baik dalam hal penyimpanannya karena data-data laporan hasil produksi bisa dibuka dan dapat dirubah oleh orang lain, bila dilihat data laporan hasil produksi yang diolah setiap harinya cukup banyak. Ini akibat kurang maksimalnya pemanfaatan teknologi komputer dengan adanya penggunaan sistem komputerisasi dapat membantu kinerja karyawan dan juga meningkatkan produktifitas karyawan, bukan hanya dalam penyimpanan data dan memberikan informasi yang cepat dan tepat, maka dalam hal ini sangat diperlukan suatu sistem pengawasan yang baik.

\section{PERMASALAHAN}

Berdasarkan latar belakang yang telah dijelaskan, maka yang menjadi rumusan permasalahan pada PT. Central Sarana Pancing adalah :

1. Bagaimana sistem yang sedang berjalan saat ini pada PT. Central Saran Pancing dalam hal pengolaan data laporan hasil produksi sudah aman dalam penyimpanan datanya?

2. Bagaimana membuat sistem pengolahan data laporan hasil produksi pada PT. Central Sarana Pancing agar menjadi lebih baik ?

3. Bagaimana menciptakan suatu sistem yang mudah, cepat dan akurat saat digunakan sehingga mampu membantu perusahaan?

\section{METODOLOGI PENELITIAN}

\section{Metode Pengumpulan Data}

Pada penelitian laporan ini, penulis telah mengumpulkan data serta mengolah informasi yang diperlukan menggunakan 2 (dua) metode sebagai berikut:

A. Metode Observasi (Observation research)

Yaitu pengumpulan data dengan cara melakukan pengamatan secara langsung dilapangan kerja yang bertempat di PT. Central Sarana Pancing yang beralamat di Jl. Raya Serang, Km.12 Kawasan Industri Bunder No. 88 Cikupa, Tangerang, observasi dilakukan guna melihat langsung proses kerja dan mengamati sistem yang sedang berjalan.

B. Metode Studi Pustaka (Library Research)

Mencari referensi yang dapat dijadikan panduan dalam penyusunan penelitian yang bersumber dari berbagai buku analisa guna mendapatkan gambaran secara teoritis yang berkaitan dengan penulisan penelitian ini.

\section{Metode Analisis}

Metode analisa sistem yang digunakan peneliti yaitu menggunakan metode SWOT. SWOT adalah sebuah metode prosedur analisa kondisi yang mengklarifikasi kondisi suatu objek dalam empat kategori Strength (Kekuatan), Weakness (Kelemahan), Opportunity (Pendukung) dan Threat (Ancaman). Terhadap sistem yang ada pada PT. Central Sarana 
Pancing sehingga dapat menganalisa apa saja yang mencakup kedalam SWOT baik faktor yang berasal dari faktor internal maupun eksternal.

\section{Metode Perancangan}

Dalam metode peracangan ini penulis menggunakan Unified Modeling Language (UML) untuk menganalisa sistem yang ada pada perusahaan, maka dalam penelitian ini penulis menggunakan program Unified Modeling Language (UML) untuk menjabarkan rancangan prosedur sistem yang berjalan.

\section{Metode Testing}

Metode testing digunakan untuk menganalisa suatu sistem untuk mendeteksi, ulasan kondisi dan fitur yang diinginkan serta mengetahui kualitas dari suatu sistem yang sedang dikembangkan, untuk mengeliminasi kesalahan yang berada di sistem pada saat diterapkan. Dalam penelitian ini peneliti menerapkan Black Box sistem dimana Black Box sistem ini berfungsi untuk mengetahui apakah perangkat lunak dapat berfungsi sebagaimana yang telah diharapkan.

\section{LITERATURE REVIEW}

Dalam upaya perlu dilakukannya studi pustaka sebagai salah satu dari penerapan metode penelitian yang akan dilakukan yaitu, dengan mengidentifikasikan kesenjangan (identify gaps), menghindari pembuatan ulang (reinventing the wheel), mengidentifikasikan metode yang pernah dilakukan, serta mengetahui penelitian lain yang spesialisasi dan area penelitian yang sama dibidang ini. Berikut adalah 10 (sepuluh) penelitian yangtelahdilakukandanmemiliki kolerasi searah dengan penelitian yang akan dibahas dalam penelitian ini, antara lain:

Tabel 1. Sumber Literature Review

\begin{tabular}{|c|c|c|c|c|c|}
\hline No & Judul & Peneliti & Metode & Hasil & Perbedaan \\
\hline 1 & $\begin{array}{l}\text { Sistem } \\
\text { Informasi } \\
\text { Manajemen } \\
\text { Produksi Unit } \\
\text { Painting \& } \\
\text { Packaging Cv. } \\
\text { Karya Hidup } \\
\text { Sentosa } \\
\text { Berbasis Web }\end{array}$ & $\begin{array}{l}\text { Yulianto, } \\
\text { Setia } \\
\text { Wardani, } \\
\text { danWibawa. } \\
\text { Universitas } \\
\text { PGRI } \\
\text { Yogyakarta } \\
\text { (2016) }\end{array}$ & $\begin{array}{l}\text { Metode } \\
\text { penelitian ini } \\
\text { dilakukan } \\
\text { dengan } \\
\text { menggunakan } \\
\text { metode } \\
\text { wawancara } \\
\text { dan metode } \\
\text { observasi } \\
\text { langsung. }\end{array}$ & $\begin{array}{l}\text { Penelituan } \\
\text { menggunakan } \\
\text { metode } \\
\text { survey dengan } \\
\text { penggunaan } \\
\text { yang sebagai } \\
\text { dengan } \\
\text { kebutuhan } \\
\text { pengguna }\end{array}$ & $\begin{array}{l}\text { Dapat digunakan } \\
\text { sebagai pedoman } \\
\text { mengembangkan } \\
\text { sistem, dan akan } \\
\text { memberikan hasil } \\
\text { sistem yang baik } \\
\text { karena system } \\
\text { dianalisis dan } \\
\text { dirancang secara } \\
\text { keseluruhan } \\
\text { sebelum di } \\
\text { implementasikan. }\end{array}$ \\
\hline 2 & $\begin{array}{l}\text { ANALISIS } \\
\text { Sistem } \\
\text { Informasi } \\
\text { Akuntansi } \\
\text { Persediaan } \\
\text { Bahan Baku } \\
\text { Dalam } \\
\text { Kelancaran } \\
\text { Proses } \\
\text { Produksi }\end{array}$ & $\begin{array}{l}\text { Achmad } \\
\text { Jawaahirul } \\
\text { Mustofa, Tri } \\
\text { Lestari dan } \\
\text { Siti } \\
\text { Rosyafah. } \\
\text { Universitas } \\
\text { Bhayangkar } \\
\text { a Surabaya } \\
\text { (2015) }\end{array}$ & $\begin{array}{l}\text { Metodologi } \\
\text { penelitian } \\
\text { yang } \\
\text { digunakan } \\
\text { adalah metode } \\
\text { kualitatif }\end{array}$ & $\begin{array}{l}\text { Dapat } \\
\text { melancarkan } \\
\text { proses } \\
\text { produksi } \\
\text { persediaan } \\
\text { bahan baku } \\
\text { mengenai } \\
\text { persediaan } \\
\text { bahan baku } \\
\text { Dengan tepat } \\
\text { agar tidak } \\
\text { terjadi } \\
\text { kekurangan } \\
\text { bahan baku. }\end{array}$ & $\begin{array}{l}\text { Dapat } \\
\text { mempercepat } \\
\text { pembuatan } \\
\text { laporan produksi, } \\
\text { sehingga semua } \\
\text { bagian rapat } \\
\text { mengetahui } \\
\text { produksi } \\
\text { tersedia yang } \\
\text { real time }\end{array}$ \\
\hline
\end{tabular}




\begin{tabular}{|c|c|c|c|c|c|}
\hline 3 & $\begin{array}{l}\text { Aplikasi } \\
\text { Berbasis } \\
\text { Web Untuk } \\
\text { Pengelolaan } \\
\text { Bahan Baku } \\
\text { Produksi } \\
\text { Menggunaka } \\
\text { n Metode } \\
\text { Economic } \\
\text { Order } \\
\text { Quantity } \\
\text { (Studi Kasus } \\
\text { Pada Ukm } \\
\text { Donat Bebek, } \\
\text { Bandung) }\end{array}$ & $\begin{array}{l}\text { Yudhi } \\
\text { Yanua. } \\
\text { Universitas } \\
\text { Telkom } \\
\text { Bandung } \\
\text { (2016) }\end{array}$ & $\begin{array}{l}\text { Metode yang } \\
\text { digunakan } \\
\text { Software } \\
\text { Development } \\
\text { Cycle (SDLC) } \\
\text { dengan } \\
\text { menggunakan } \\
\text { metode } \\
\text { waterfal }\end{array}$ & $\begin{array}{l}\text { Sistem yang } \\
\text { dibangun } \\
\text { dapat } \\
\text { menghitung } \\
\text { EOQ yang } \\
\text { diperlukan } \\
\text { untuk } \\
\text { melakukan } \\
\text { pembelian } \\
\text { bahan baku }\end{array}$ & $\begin{array}{lr}\text { Sistem } & \text { dapat } \\
\text { menghitung } & \text { stock } \\
\text { persedian } & \text { barang } \\
\text { dalam } & \text { gudang } \\
\text { sebelum } & \text { pihak } \\
\text { marketing } & \\
\text { melakukan } & \\
\text { penjualan } & \end{array}$ \\
\hline 4 & $\begin{array}{l}\text { Analisis Dan } \\
\text { Perancangan } \\
\text { Sistem } \\
\text { Informasi } \\
\text { Terintegrasi } \\
\text { Untuk } \\
\text { Manajemen } \\
\text { Produksi, } \\
\text { Persediaan Dan } \\
\text { Distribusi } \\
\text { Barang }\end{array}$ & $\begin{array}{l}\text { Zaidir1 dan } \\
\text { Andreas } \\
\text { Ardani. } \\
\text { Universitas } \\
\text { Respati } \\
\text { Yogyakarta } \\
\text { (2017) }\end{array}$ & $\begin{array}{l}\text { Metode yang } \\
\text { digunakan } \\
\text { dalam } \\
\text { penelitian ini } \\
\text { adalah dengan } \\
\text { studi } \\
\text { kepustakaan, } \\
\text { pengumpulan } \\
\text { data, dan } \\
\text { pengembanga } \\
\text { n system } \\
\text { terintegrasi }\end{array}$ & $\begin{array}{l}\text { Rancangan } \\
\text { system } \\
\text { terintegrasi } \\
\text { yang dapat } \\
\text { mempermuda } \\
\mathrm{h} \text { dan } \\
\text { mempercepat } \\
\text { dalam } \\
\text { pengelolaan } \\
\text { produksi, } \\
\text { persediaan } \\
\text { dan distribusi } \\
\text { barang serta } \\
\text { membantu } \\
\text { manajemen } \\
\text { dalam proses } \\
\text { pengambilan } \\
\text { keputusan }\end{array}$ & $\begin{array}{l}\text { Dapat } \\
\text { mempermudah } \\
\text { pekerjaan admin } \\
\text { produksi dan } \\
\text { manajemen dalam } \\
\text { membuat laporan } \\
\text { harian, bulanan } \\
\text { dan tahunan secara } \\
\text { cepat dan tepat }\end{array}$ \\
\hline 5 & $\begin{array}{l}\text { Penerapan } \\
\text { Enterprise } \\
\text { Resource } \\
\text { Planning } \\
\text { (ERP) } \\
\text { Pengadaan } \\
\text { Bahan Dan } \\
\text { Pengelolaan } \\
\text { Produksi Pada } \\
\text { Perusahaan } \\
\text { Furniture } \\
\text { Menggunakan } \\
\text { Adempiere }\end{array}$ & $\begin{array}{l}\text { Hasdi dan } \\
\text { Ravi Azhari. } \\
\text { Universitas } \\
\text { Andalas, } \\
\text { Padang } \\
\text { (2016) }\end{array}$ & $\begin{array}{l}\text { Sistem ini } \\
\text { menggunakan } \\
\text { Aplaksi } \\
\text { ADempire } \\
\text { untuk } \\
\text { mengimpleme } \\
\text { ntasikan ERP } \\
\text { (Enterprise } \\
\text { Resource } \\
\text { Planning) } \\
\text { pada tempat } \\
\text { penelitian }\end{array}$ & $\begin{array}{l}\text { Menghasilkan } \\
\text { sebuah } \\
\text { laporan } \\
\text { keuangan } \\
\text { sesuai dengan } \\
\text { kebutuhan } \\
\text { perusahaan, } \\
\text { Mengelola } \\
\text { bahan baku } \\
\text { untuk proses } \\
\text { produksi }\end{array}$ & $\begin{array}{l}\text { Menghasilkan } \\
\text { laporan produksi } \\
\text { dengan kwalitas } \\
\text { baik dan buruknya } \\
\text { saat QC mengecek } \\
\text { hasil pembuatan } \\
\text { produksi }\end{array}$ \\
\hline 6 & $\begin{array}{l}\text { Analisis Dan } \\
\text { Perancangan } \\
\text { Sistem } \\
\text { Informasi } \\
\text { Administrasi }\end{array}$ & $\begin{array}{l}\text { Rosmalina. } \\
\text { Universitas } \\
\text { Bale } \\
\text { Bandung } \\
(2017)\end{array}$ & $\begin{array}{l}\text { Metode yang } \\
\text { digunakan } \\
\text { untuk } \\
\text { merancang } \\
\text { yaitu system }\end{array}$ & $\begin{array}{l}\text { Terbuatnya } \\
\text { rancangan } \\
\text { system } \\
\text { informasi } \\
\text { administrasi }\end{array}$ & $\begin{array}{l}\text { Terbuatnya sebuah } \\
\text { system } \\
\text { pengelolaan } \\
\text { laporan produksi } \\
\text { yang berbasis web }\end{array}$ \\
\hline
\end{tabular}




\begin{tabular}{|c|c|c|c|c|c|}
\hline & $\begin{array}{l}\text { Produksi } \\
\text { Departemen } \\
\text { Sizing }\end{array}$ & & $\begin{array}{l}\text { Depelopment } \\
\text { life cycle } \\
\text { dengan alat } \\
\text { pemodelan } \\
\text { system } \\
\text { menggunakan } \\
\text { UML } \\
\text { (Unified } \\
\text { Modelling } \\
\text { Language) }\end{array}$ & $\begin{array}{l}\text { produksi } \\
\text { departemen } \\
\text { sizing. }\end{array}$ & $\begin{array}{l}\text { site sesuai dengan } \\
\text { kebutuhan } \\
\text { dilapangan. }\end{array}$ \\
\hline 7 & $\begin{array}{l}\text { Perancangan } \\
\text { Sistem } \\
\text { Informasi } \\
\text { Produksi Pada } \\
\text { Perusahaan } \\
\text { Manufaktur } \\
\text { Menggunakan } \\
\text { Metode SDLC }\end{array}$ & $\begin{array}{l}\text { Priskila } \\
\text { Christine } \\
\text { Rahayu, } \\
\text { Natalia } \\
\text { Hartono, } \\
\text { Nugroho } \\
\text { Darmawan } \\
\text { Indraputra } \\
\text { (Universitas } \\
\text { Pelita } \\
\text { Harapan, } \\
\text { 2017) }\end{array}$ & $\begin{array}{l}\text { Metode } \\
\text { penelitian ini } \\
\text { menggunakan } \\
\text { metode SDLC } \\
\text { (System } \\
\text { Development } \\
\text { Life Cycle) }\end{array}$ & $\begin{array}{l}\text { Dapat } \\
\text { mengurangi } \\
\text { kesalahan } \\
\text { dalam } \\
\text { pencatatan } \\
\text { data produksi } \\
\text { dan } \\
\text { menyederhan } \\
\text { akan } \\
\text { persiapan } \\
\text { lapororan } \\
\text { produksi. }\end{array}$ & $\begin{array}{l}l \\
\text { Peneliti } \\
\text { menggunakan } \\
\text { metode SDLC } \\
\text { untuk mengurangi } \\
\text { kesalahan dalam } \\
\text { pembuatan } \\
\text { laporan } \\
\text { produsi. }\end{array}$ \\
\hline 8 & $\begin{array}{l}\text { Pendekatan } \\
\text { Classic Life } \\
\text { Cycle Dalam } \\
\text { Perancangan } \\
\text { Web E- } \\
\text { Commerce } \\
\text { Untuk } \\
\text { Penjualan } \\
\text { Pakaian Anime }\end{array}$ & $\begin{array}{l}\text { Joni Pranata } \\
\text { Sentosa , } \\
\text { Nunung } \\
\text { Hidayatun } \\
\text { (STMIK } \\
\text { ANTAR } \\
\text { BANGSA,2 } \\
016 \text { ) }\end{array}$ & $\begin{array}{l}\text { Metode clasic } \\
\text { life cycle/ } \\
\text { waterfall. }\end{array}$ & $\begin{array}{l}\text { Dapat } \\
\text { menghemat } \\
\text { biaya } \\
\text { operasional, } \\
\text { biaya promosi } \\
\text { dan waktu } \\
\text { kerja } \\
\text { dibandingkan } \\
\text { dengan } \\
\text { pemesanan } \\
\text { secara } \\
\text { langsung dan } \\
\text { pembeli dapat } \\
\text { melihat } \\
\text { kategori } \\
\text { produk } \\
\text { dihalaman } \\
\text { website ini }\end{array}$ & $\begin{array}{l}\text { Dapat menghemat } \\
\text { biaya kertas pada } \\
\text { pembuatan } \\
\text { laporan, } \\
\text { menghemat waktu } \\
\text { saat merekap hasil } \\
\text { produksi laporan } \\
\text { harian menjadi } \\
\text { laporan bulanan } \\
\text { dan tahunan }\end{array}$ \\
\hline 9 & $\begin{array}{l}\text { The } \\
\text { Comparative } \\
\text { Study Of } \\
\text { Collaborative } \\
\text { Learning And } \\
\text { Sdlc Model To } \\
\text { Develop It } \\
\text { Group Projects }\end{array}$ & $\begin{array}{l}\text { Sorapak Puk } \\
\text { desree } \\
\text { (Bangkok } \\
\text { University,P } \\
\text { athumthani, } \\
\text { Thailand, } \\
\text { 2017) }\end{array}$ & $\begin{array}{l}\text { SDLC model, } \\
\text { Waterfall } \\
\text { model, } \\
\text { Collaborative } \\
\text { Learning, IT } \\
\text { group } \\
\text { projects. }\end{array}$ & $\begin{array}{l}\text { Untuk } \\
\text { mengembang } \\
\text { kan } \\
\text { courseware e- } \\
\text { lerning } \\
\text { computer } \\
\text { kursus } \\
\text { organisasi } \\
\text { dana rsitektur } \\
\text { sebagai TI } \\
\text { proyek } \\
\text { kelompok (To }\end{array}$ & $\begin{array}{l}\text { Untuk } \\
\text { mengembangkan } \\
\text { system laporan } \\
\text { yang lebih baik } \\
\text { dan efisien. }\end{array}$ \\
\hline
\end{tabular}




\begin{tabular}{|c|c|c|c|c|c|}
\hline & & & & $\begin{array}{l}\text { develop e- } \\
\text { learning } \\
\text { courseware of } \\
\text { Computer } \\
\text { Organization } \\
\text { and } \\
\text { Architecture } \\
\text { course as IT } \\
\text { group } \\
\text { projects) }\end{array}$ & \\
\hline 10 & $\begin{array}{l}\text { Perancangan } \\
\text { Sistem } \\
\text { Informasi } \\
\text { Berbasis } \\
\text { Desktop Untuk } \\
\text { Pengelolaan } \\
\text { Data Transaksi } \\
\text { Dan Laporan } \\
\text { Keuangan Pada } \\
\text { In Tailor } \\
\text { Menggunakan } \\
\text { Metode } \\
\text { Waterfall }\end{array}$ & $\begin{array}{l}\text { Fran Serano } \\
\text { Andres } \\
\text { Budi } \\
\text { Praptono, } \\
\text { WawanTripi } \\
\text { awan } \\
\text { (Telkom } \\
\text { University, } \\
\text { 2017) }\end{array}$ & $\begin{array}{l}\text { SDLC model, } \\
\text { Waterfall } \\
\text { model }\end{array}$ & \begin{tabular}{lr}
\multicolumn{2}{l}{ Dapat } \\
meningkatkan \\
mutu dan \\
kinerja $\quad$ IN \\
Tailor serta \\
dapat & \\
membantu \\
pendataan \\
pada \\
Tailor \\
menjadi \\
tepat lebih \\
akurat.
\end{tabular} & $\begin{array}{l}\text { Dapat } \\
\text { meningkatkan } \\
\text { system laporan } \\
\text { yang lebih baik } \\
\text { dan efisien. }\end{array}$ \\
\hline
\end{tabular}

\section{Analisis SWOT}

Berikut ini merupakan penjelasan analisis SWOT yang diusulkan dimana pada analisis ini mengidentifikasi Strenght (kekuatan) dan Weakness (kelemahan) yang merupakan faktor internal dan Opportunities (Peluang) dan Threats (Ancaman) yaitu merupakan faktor eksternal. Berikut ini merupakan tabel analisa SWOT yang diusulkan:

Tabel 1. Analisis SWOT Yang Diusulkan

\begin{tabular}{|l|l|l|}
\hline & Awal Analisa & Akhir Analisa \\
\hline $\begin{array}{l}\text { Strenghts } \\
\text { (Kekuatan) }\end{array}$ & $\begin{array}{l}\text { Proses pencatatan laporan hasil } \\
\text { produksi masih manual. }\end{array}$ & $\begin{array}{l}\text { Pencatatan laporan hasil produksi } \\
\text { sudah menggunakan sistem. }\end{array}$ \\
\hline $\begin{array}{l}\text { Weaknesses } \\
\text { Kelemahan) }\end{array}$ & $\begin{array}{l}\text { Sistem pengolahan laporan hasil } \\
\text { produks masih menggunakan } \\
\text { kertas sehingga dapat menimbulkan } \\
\text { kesalahan dalam pemrosesan data, } \\
\text { selain itu pemrosesan data akan } \\
\text { memakan banyak waktu. }\end{array}$ & $\begin{array}{l}\text { Pengolahan laporan hasil produksi } \\
\text { lebih efisien dan efektif dalam hal } \\
\text { pengolahan datanya. }\end{array}$ \\
\hline $\begin{array}{l}\text { Opportunity } \\
\text { (Kesempatan) }\end{array}$ & $\begin{array}{l}\text { Dibutuhkan suatu sistem yang } \\
\text { mengontrol dan menangani data } \\
\text { produksi yang efisien dan realtime }\end{array}$ & $\begin{array}{l}\text { Maka dibutuhkan suatu system } \\
\text { informasi pengolahan data laporan } \\
\text { hasil produksi berbasis WEB } \\
\text { Online. }\end{array}$ \\
\hline $\begin{array}{l}\text { Threat } \\
\text { (Ancaman) }\end{array}$ & $\begin{array}{l}\text { Perkembangan informasi yang } \\
\text { semakin cepat dan canggih. }\end{array}$ & $\begin{array}{l}\text { Sudah mampu mencetak laporan } \\
\text { hasil produksi. }\end{array}$ \\
\hline
\end{tabular}




\section{HASIL DAN PEMBAHASAN}

\section{Use Case Diagram yang Dirancang}

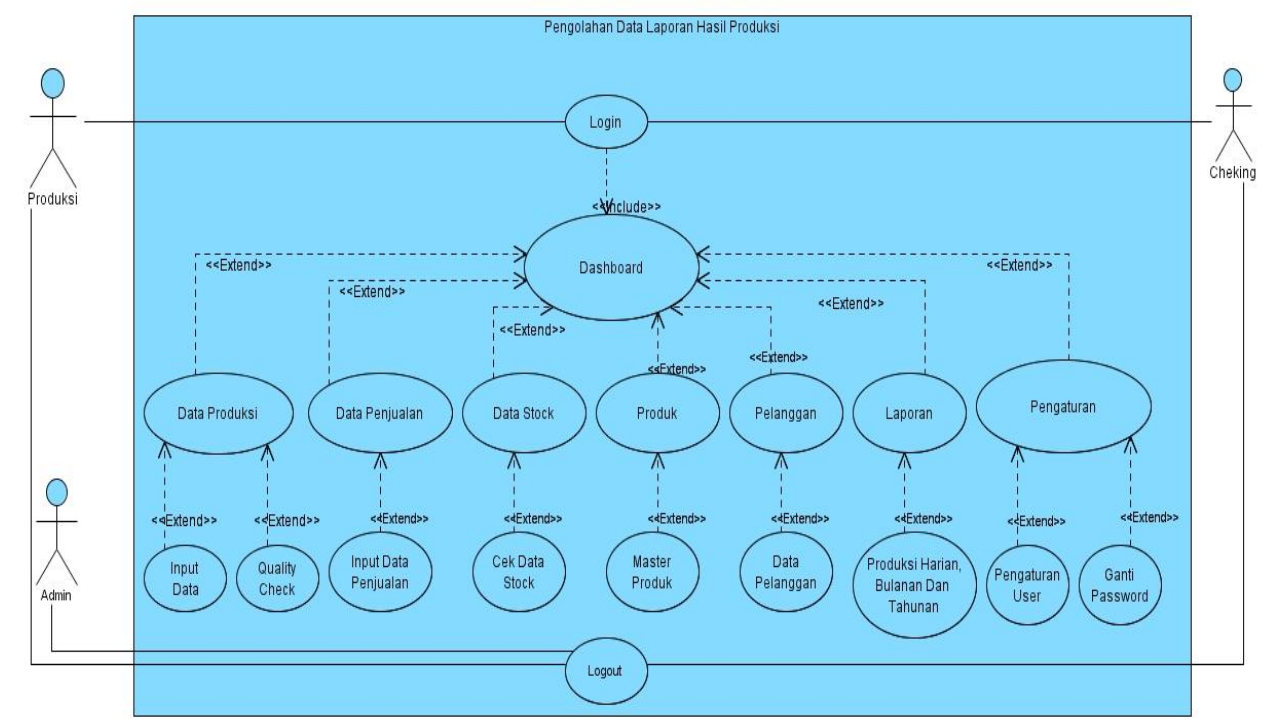

Gambar 1. Use Case Diagram

Dapat dijelaskan gambar diatas merupakan use case diagram yang diusulkan, yaitu terdiri dari:

a. 3 Actor yang terdiri dari Produksi, Cheking Dan Admin.

b. 19 Usecasedalam kegiatan yang digunakan Actor dalam sistem pengolahan data laporan hasil produksi.

c. 1Extends yang merupakan pilihan dari usecase yang terdiri dari menampilkan menu sistem (Dashboard).

d. 1 Include yang menjelaskan bahwa usecase berasal dari sumber secara eksplisit pada usecase sebelumnya.

\section{Activity Diagram Yang Dirancang}

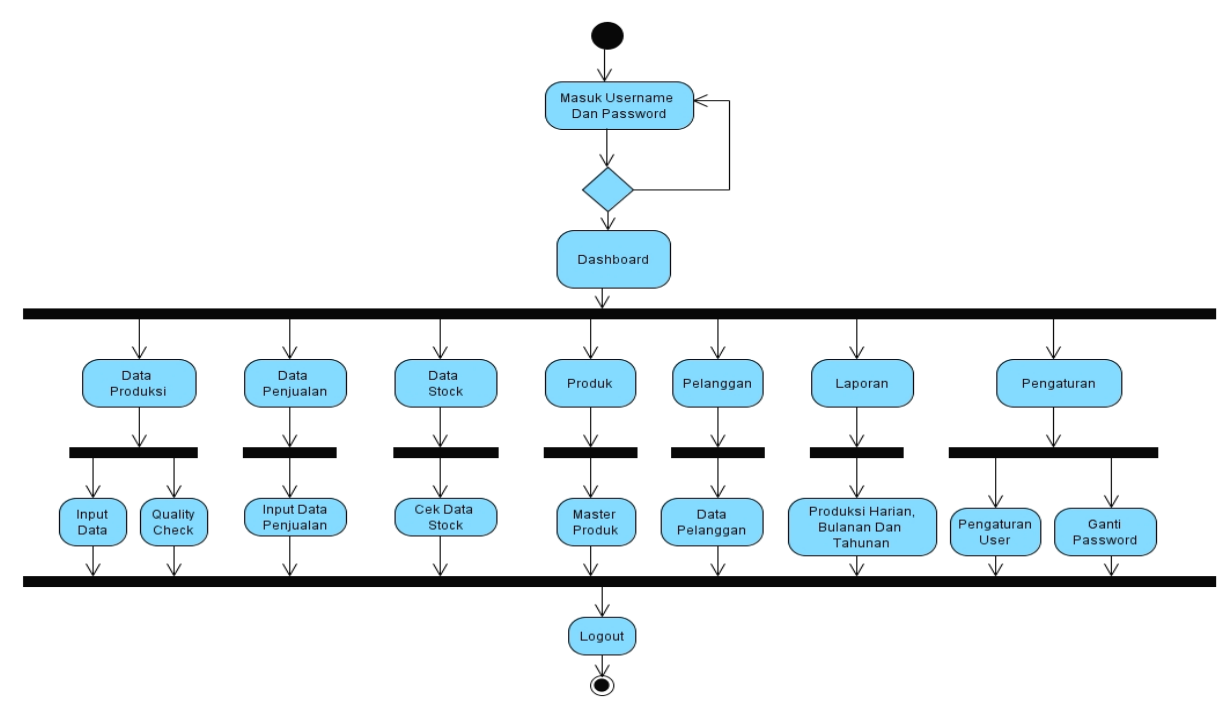

Gambar 2. Activity Diagram 
Dapat dijelaskan dari gambar di atas yang merupakan gambar activity diagram sistem informasi terdapat:

a. Tiga intial node, sebagai awal objek.

b. Terdapat 16action, state dari sistem yang mencerminkan eksekusi dari semua aksi.

c. Satu final node, objek yang diakhiri.

\section{Sequence Diagram Yang Dirancang}

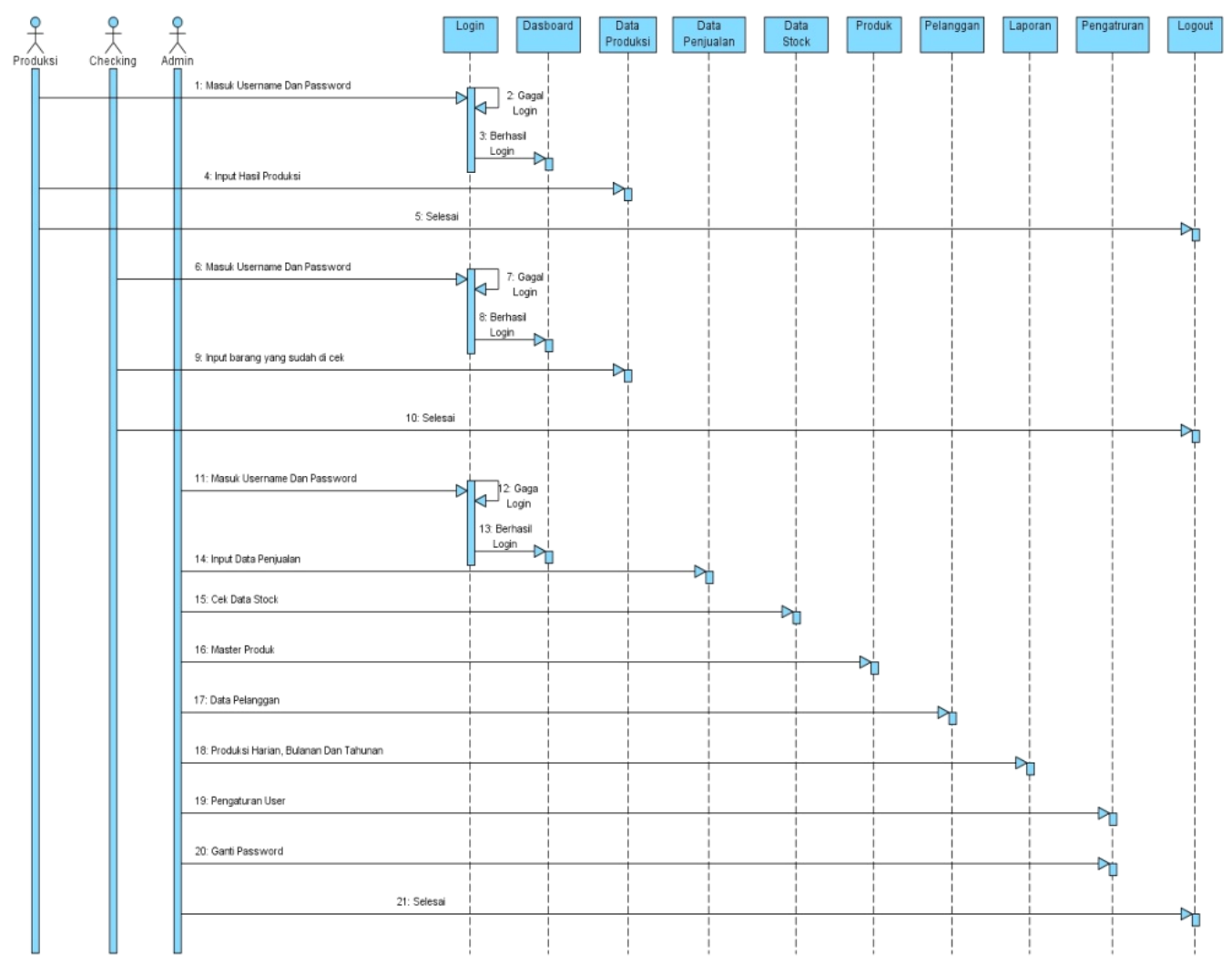

Gambar 3. Sequence Diagram

Gambar 3. Sequence Diagram yang diusulkan diatas menggambarkan sequence diagram yang berjalan, yaitu sebagai berikut:

a. 10 lifeline antar muka yang saling berinteraksi.

b. 3 aktor yang melakukan kegiatan yaitu produksi, checking dan admin.

c. 21 message spesifikasi dari kamunikasi antar objek yang memuat informasi-informasi tentang aktifitas yang terjadi.

d. 1 decision node untk memberkan keputusan.

\section{IMPLEMENTASI}

\section{Tampilan Layar Sistem Yang Diusulkan}

Pada tahap ini akan menampilkan tentang tampilan layar sistem yang penulis usulkan. Diantaranya yaitu 
1. Tampilan Login

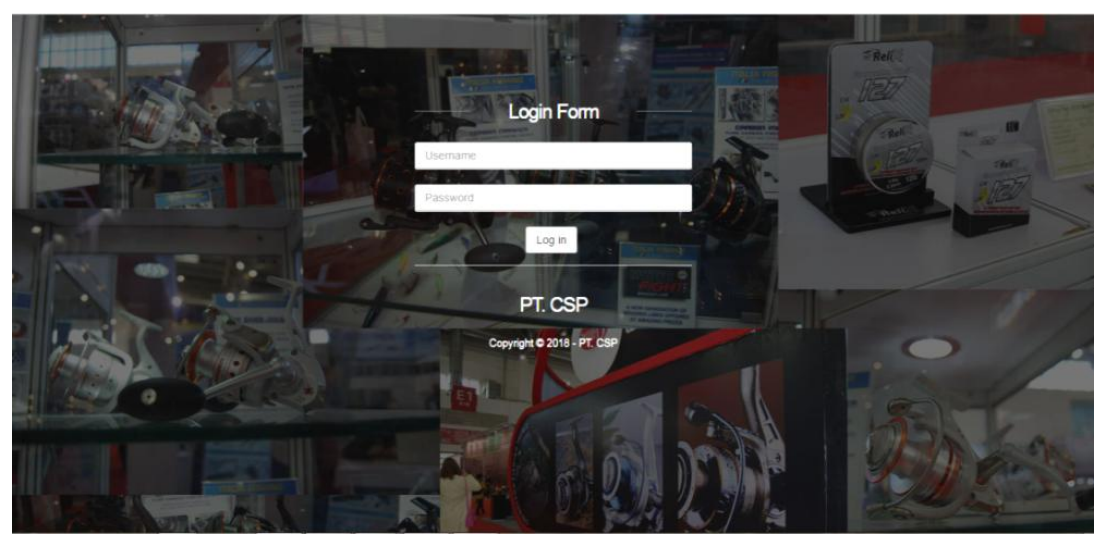

Gambar 4. Tampilan Login

Tampilan login pada gambar diatas merupakan tampilan awal sistem, yang didalamnya terdapat perintah untuk memasukan username dan password. Pada login sistem membagi tiga hak akses diantaranya Operator, Quality Check (QC) dan Admin.

2. Tampilan dashboard

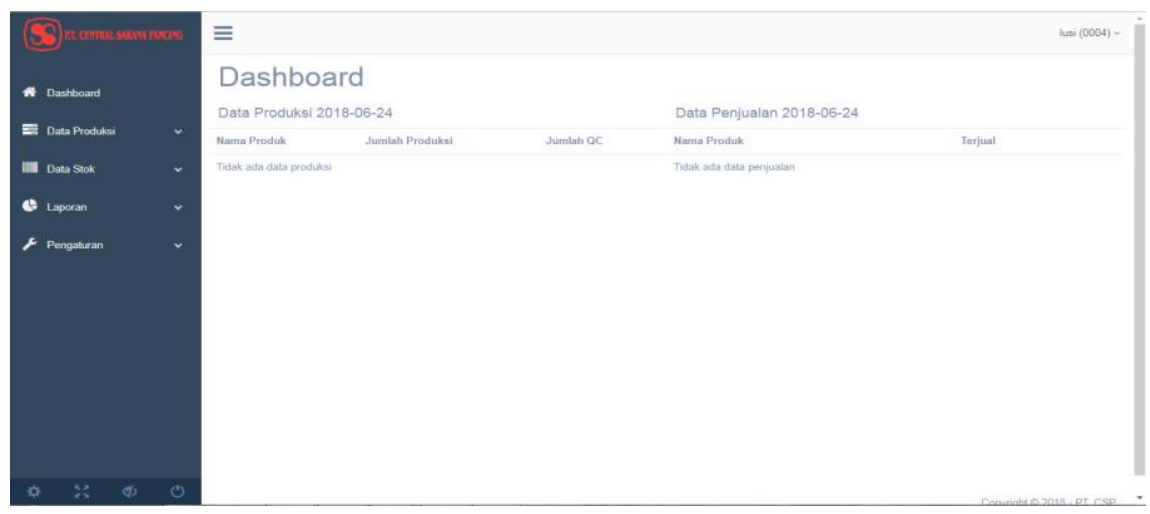

Gambar 5. Tampilan Halaman Dashboard

Pada gambar diatas merupakan tampilan dashboard dari sistem pengolahan data laporan hasil produksi dimana sistem menampilkan data harian yang terudate secara otomatis berdasarkan data pada database yang telah dilakukan proses penginputan maupun pengeluaran. 3. Tampilan Input Data Produksi

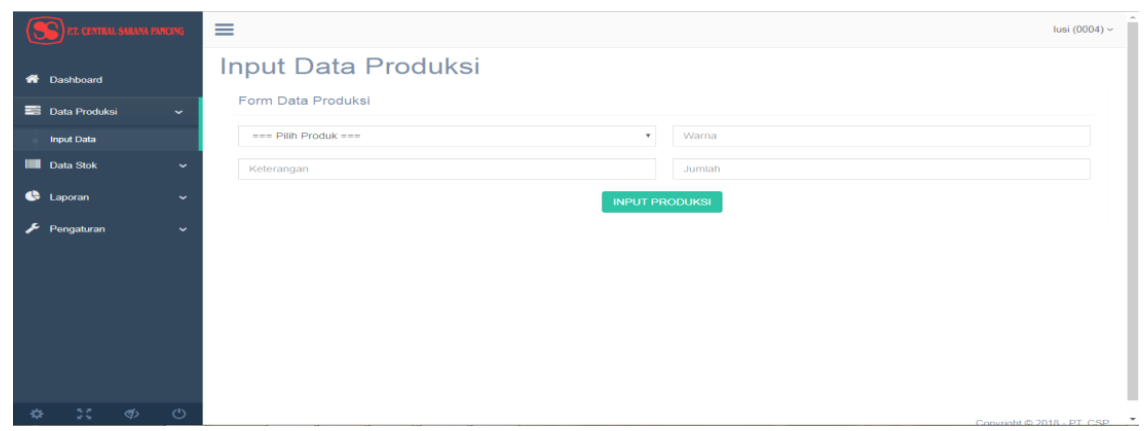

Gambar 6. Tampilan Input Data Produksi 
Pada gambar diatas merupakan tampilan input data produksi yang didalamnya berisi form data produksi sebagai tempat untuk melakukan penginputan.

\section{Tampilan Data Quality Check}

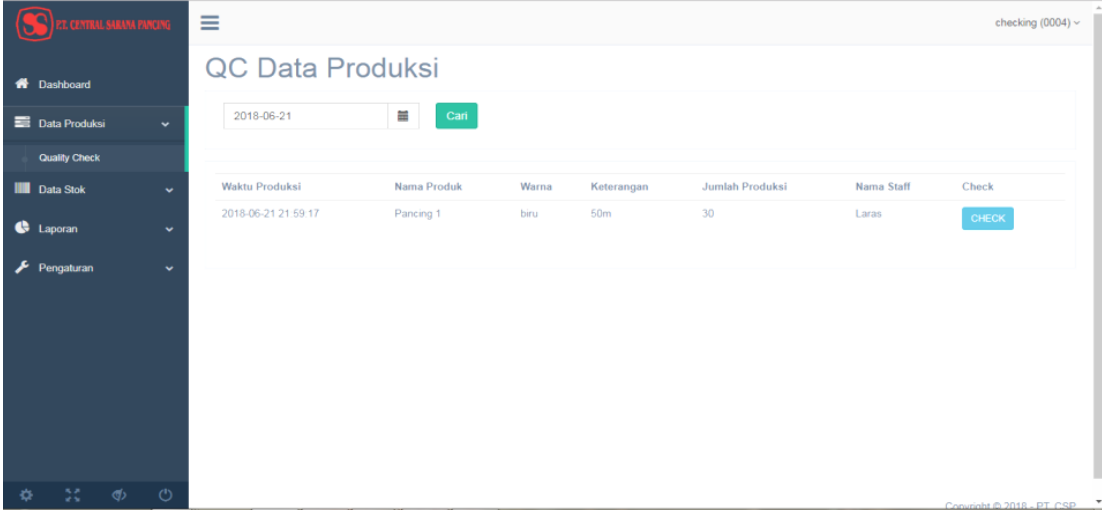

Gambar 7. Tampilan Data Quality Check

Pada gambar diatas merupakan tampilan QC Data Produksi yang menampilkan hasil inputan produksi dan proses kelanjutan dari penginputan data produksi serta penentuan apakah data yang diinput telah melakukan proses checking.

5. Tampilan Penjualan

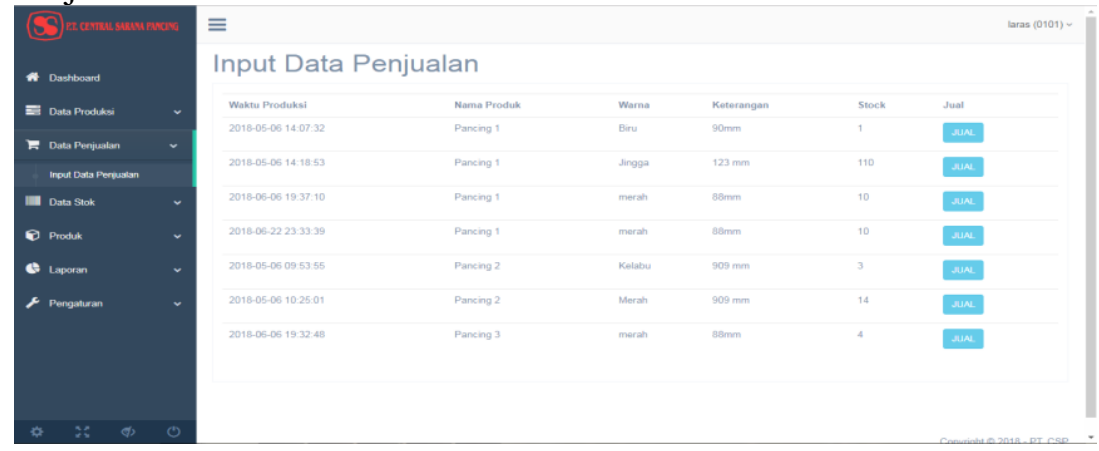

Gambar 8. Tampilan Menu Penjualan

Pada gambar diatas merupakan tampilan dari data penjualan. Dimana data penjualan ini merupakan kelanjutan dari data produksi yang di input dan telah melalui proses check.

6. Tampilan Pelanggan

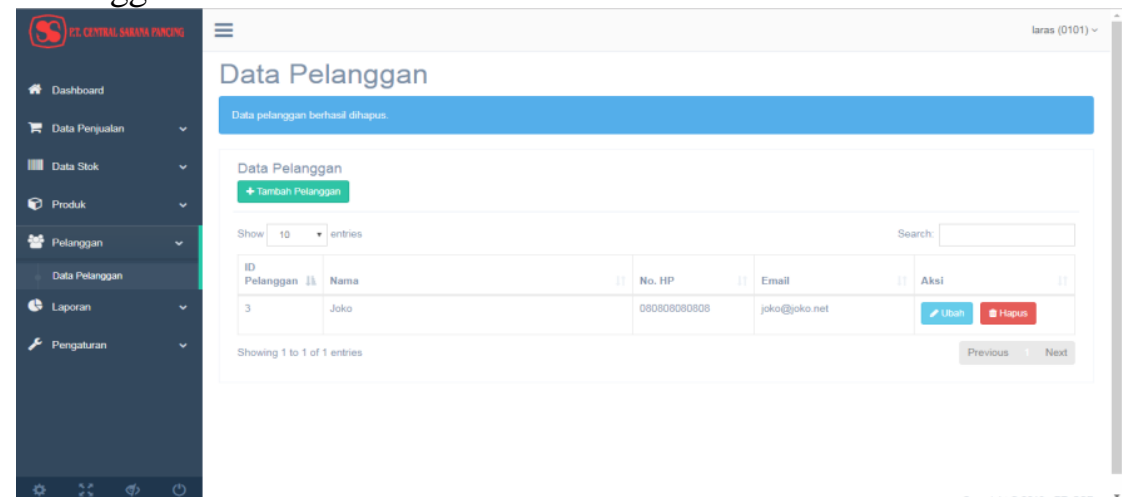

Gambar 9. Tampilan Menu Pelanggan 
Tampilan diatas merupakan tampilan untuk menambahkan nama pelanggan dan yang dapat mengakses hanya admin.

7. Tampilan Data Stock

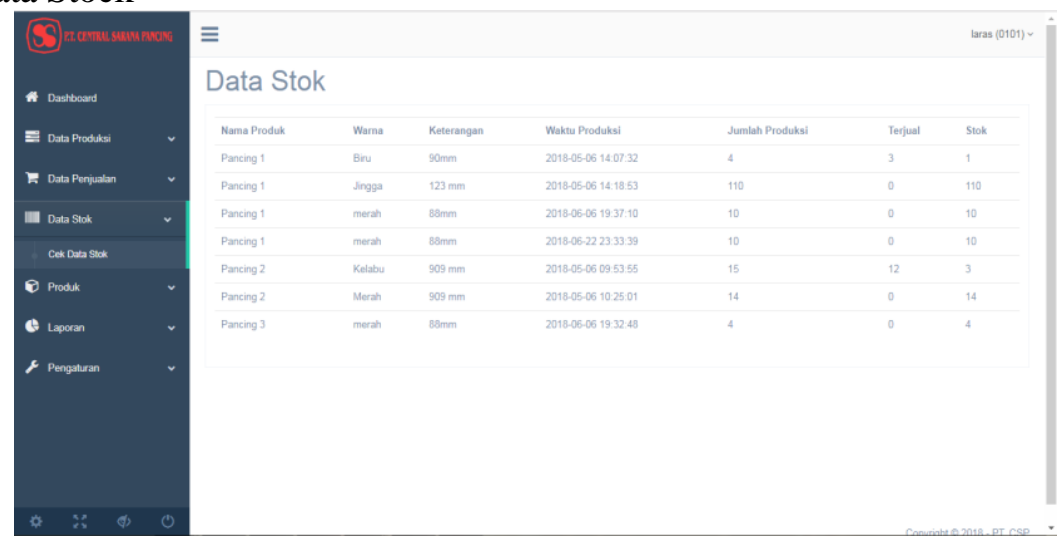

Gambar 10. Tampilan Data Stock

Pada gambar diatas merupakan data stok dari barang telah dilakukan produksi dan telah dilakukan pengurangan terhadap produk yang telah dijual.

8. Tampilan Produk

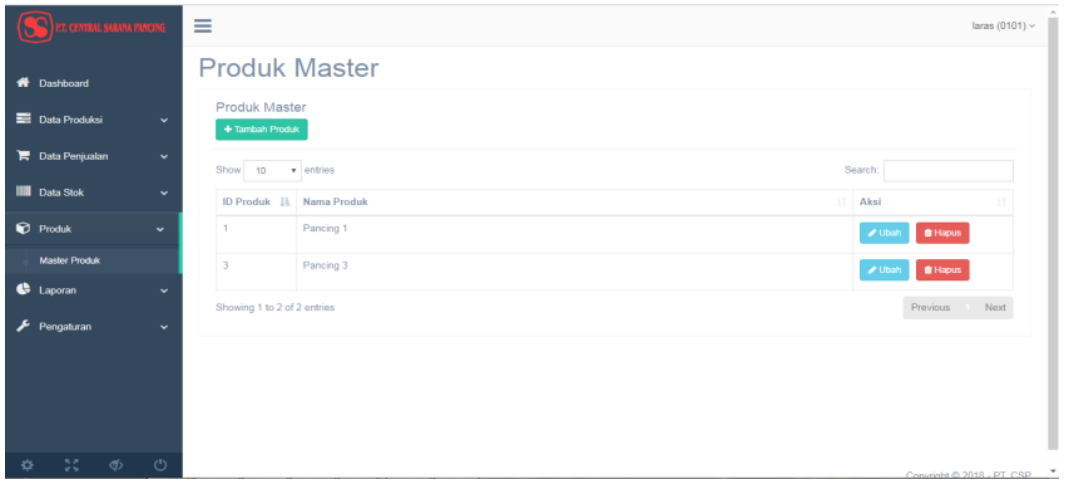

Gambar 11. Tampilan Menu Produk

Pada gambar diatas merupakan tampilan dari master produk yang didalamnya mencakup produk apa yang akan diproduksi.

9. Tampilan Laporan
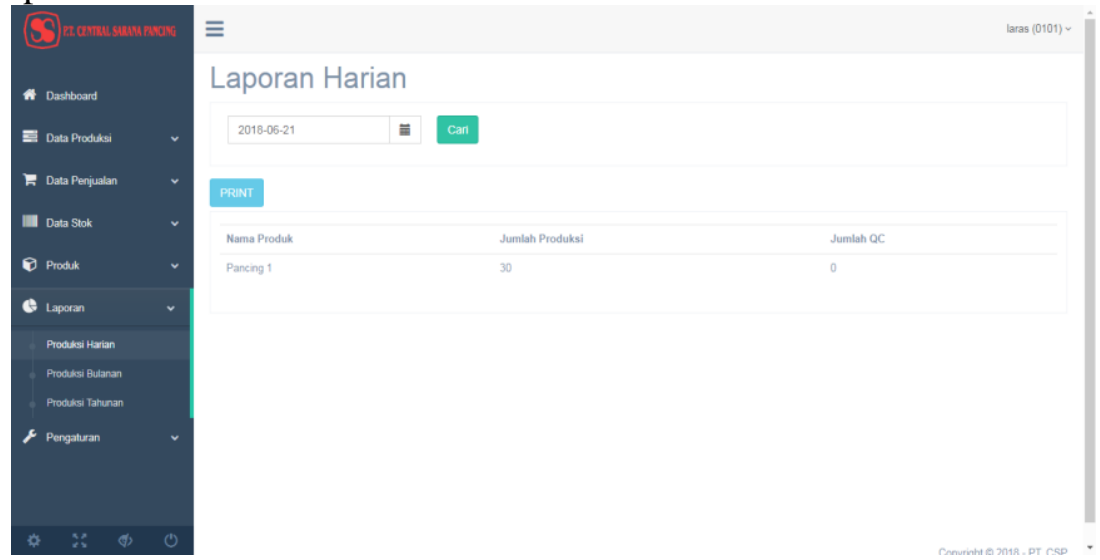

Gambar 12. Tampilan Menu Laporan 
Tampilan diatas merupakan tampilan laporan dari hasil pengolahan data prosuksi yang dapat diklasifikasikan menjadi laporan harian, laporan bulanan dan laporan tahunan sesuai dengan data yang ada dalam database.

10. Tampilan Pengaturan User

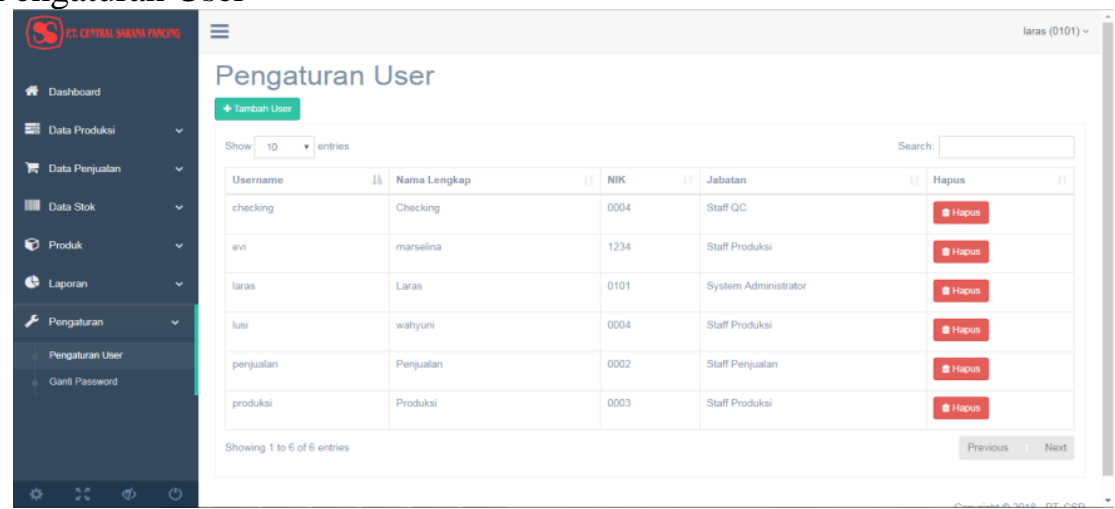

Gambar 13. Tampilan Penganturan User

Tampilan diatas merupakan tampilan untuk menentukan pengguna yang dapat masuk ke dalam sistem hasil pengolahan data produksi dengan hak akses yang terdiri dari Admin, Operator dan Quality Check.

\section{Tampilan Pengaturan Ganti Password}

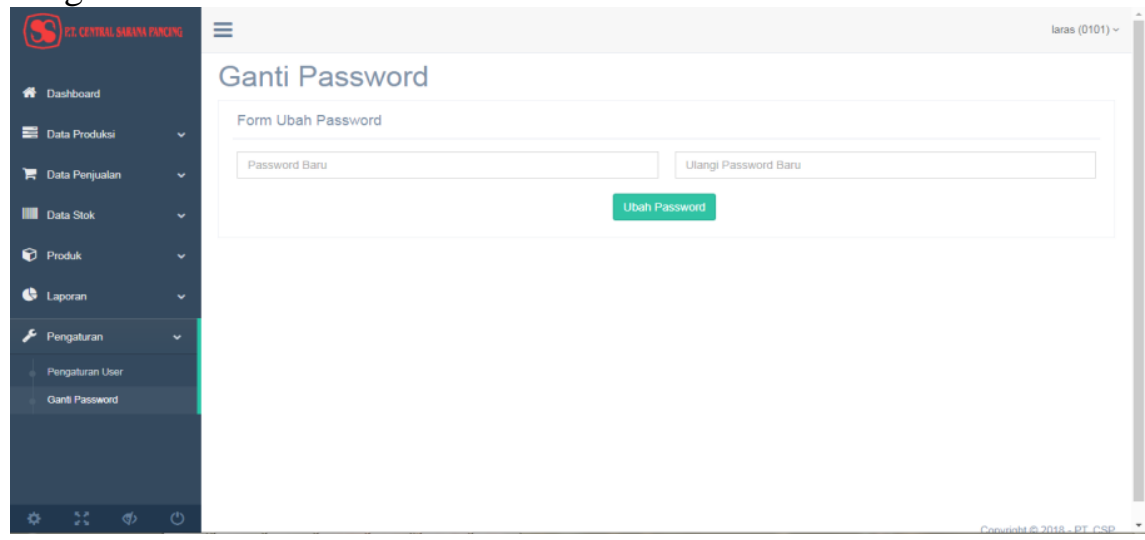

Gambar 14. Tampilan Pengaturan Ganti Password

Tampilan diatas merupakan sebuah fiture untuk mengubah password user.

\section{KESIMPULAN}

Berdasarkan dari hasil penelitian dan pengamatan yang telah dilakukan, maka dapat disimpulkan beberapa hal sebagai berikut :

1. Sistem yang sedang berjalan pada PT. Central Sarana Pancing untuk saat ini terutama dalam hal pengolahan data laporan hasil produksi dalam penyimpanan data-datanya masih kurang aman dan kurang tertata secara baik karena tidak ada tempat penyimpanan data yang baik seperti kertas laporan hasil produksi tertumpuk diatas meja sehingga laporan hasil produksi bias hilang dan tercampur dengan laporan hasil produksi yang sudah terinput.

2. Sistem yang seharusnya dibuat dan ada pada PT. Central Sarana Pancing yaitu dapat mendata secara keseluruhan dari setiap data yang akan dilakukan pengolahan mulai dari tahap penginputan sampai pada tahap laporan terkait hasil produksi yang dihasilkan. 
3. Dengan adanya sistem pengolahan data ini yang diperlukan lebih mudah, cepat dan akurat. Jika tetap menggunakan sistem yang manual akan memakan waktu yang cukup lama dan data yang dihasilkan terkadang tidak akurat sehingga menurunkan kualitas atau kerja bahkan dapat terjadi kerugian diperusahaan tersebut.

\section{SARAN}

Dalam penerapan sistem yang berjalan, penulis ingin mengemukakan saran-saran agar sistem bisa berjalan dengan baik, diantaranya :

1. PT. Central Sarana Pancing harus selalu melakukan update dan maintenance terhadap sistem pengolahan data laporan produksi yang telah dibuat untuk dapat menunjang dan mempermudah bagian produksi dalam melakukan pengolahan data yang disesuaikan dengan kebutuhan user.

2. PT. Central Sarana Pancing harus dapat mengembangkan media penyimpanan data yang terdapat dalam sistem atau perlu dilakukan backup data yang tersimpan dalam sistem ke arah yang lebih maju seperti halnya media penyimpanan online atau cloud storage.

3. PT. Central Sarana Pancing harus melakukan pengembangan terhadap sistem pengolahan data laporan hasil produksi untuk dapat diakses dengan cepat, mudah dan akurat tanpa terikat waktu dan tempat. Untuk saat ini sistem yang ada dibuat masih bersifat lokal. Sehingga akan lebih baik jika sistem tersebut diarahkan pada cloud computing.

\section{DAFTAR PUSTAKA}

[1] Yulianto Yulianto, Setia Wardani, Wibawa Wibawa. 2016. SISTEM INFORMASI MANAJEMEN PRODUKSI UNIT PAINTING \& PACKAGING CV. KARYA HIDUP SENTOSA BERBASIS WEB. Vol 5, No 2 (2016): Jurnal Dinamika Informatika Volume 5 Nomor 2.

[2] Achmad Jawaahirul Mustofa, Tri Lestari, Siti Rosyafah. 2015. ANALISIS SISTEM INFORMASI AKUNTANSI PERSEDIAAN BAHAN BAKU DALAM KELANCARAN PROSES PRODUKSI (Study Kasus Pada UD. Bintang Terang Surabaya). Jurnal Akuntansi UBHARA.

[3] Yudhi Yanuar, Julia Euneke Masakke, Raswyshnoe Boing Kotjoprayudhi. 2016. Aplikasi Berbasis Web Untuk Pengelolaan Bahan Baku Produksi Menggunakan Metode Economic Order Quantity (studi Kasus Pada Ukm Donat Bebek, Bandung). Universitas Telkom Bandung. Page 1255-1261. ISSN : 2442-5826.

[4] Zaidir, Andreas Ardani. "ANALISIS DAN PERANCANGAN SISTEM INFORMASI TERINTEGRASI UNTUK MANAJEMEN PRODUKSI, PERSEDIAAN DAN DISTRIBUSI BARANG (STUDI KASUS: PABRIK KEMASAN KERTAS CV. YOGYAKARTAS)." Jurnal Teknologi Informasi Respati 12.2 (2017).

[5] Putra, Hasdi \& Azhari, Ravi. (2016). Penerapan Enterprise Resource Planning (ERP) Pengadaan Bahan Baku dan Pengelolaan Produksi Pada Perusahaan Furniture Menggunakan ADempiere (Studi Kasus: CV Roland Kencana). Jurnal Teknologi dan Sistem Informasi. 2. 117. 10.25077/TEKNOSI.v2i3.2016.117-128.

[6] Rosmalina, R. (2017). ANALISIS DAN PERANCANGAN SISTEM INFORMASI ADMINISTRASI PRODUKSI DEPARTEMEN SIZING STUDI KASUS: PT. MALAKASARI TEXTILE MILLS. Jurnal Teknologi Informasi dan Elektronika (INFOTRONIK), 2(1).

[7] Rahayu, P. C., Hartono, N., \& Indraputra, N. D. 2017. PERANCANGAN SISTEM INFORMASI PRODUKSI PADA PERUSAHAAN MANUFAKTUR MENGGUNAKAN METODE SDLC. 
[8] Pranta, J., \& Hidayatun, N. (2016). Pendekatan Classic Life Cycle dalam Perancangan Web E-Commerce untuk Penjualan Pakaian Anime. IJCIT (Indonesian Journal on Computer and Information Technology), 1(1).

[9] Pukdesree, S. (2017). The Comparative Study of Collaborative Learning and SDLC Model to develop IT Group Projects. TEM JOURNAL-TECHNOLOGY EDUCATION MANAGEMENT INFORMATICS, 6(4), 800-809.

[10] Andres, F., Praptono, B., \& Tripiawan, W. (2017). Perancangan Sistem Informasi Berbasis Desktop Untuk Pengelolaan Data Transaksi Dan Laporan Keuangan Pada In Tailor Menggunakan Metode Waterfall. eProceedings of Engineering, 4(3). 